$\begin{array}{ll}\text { Abstracta Iranica } & \begin{array}{l}\text { Abstracta Iranica } \\ \text { Revue bibliographique pour le domaine irano-aryen }\end{array} \\ & \text { Volume } \mathbf{2 6} \mid \mathbf{2 0 0 5} \\ & \text { Comptes rendus des publications de } \mathbf{2 0 0 3}\end{array}$

\title{
L'âme des sons. Gordes, le Relié, 237 pp.
}

\section{Sāsān Fātemī}

\section{OpenEdition}

Journals

Édition électronique

URL : http://journals.openedition.org/abstractairanica/714

ISSN : 1961-960X

Éditeur :

CNRS (UMR 7528 Mondes iraniens et indiens), Éditions de l'IFRI

Édition imprimée

Date de publication : 15 mai 2005

ISSN : 0240-8910

\section{Référence électronique}

Sāsān Fātemī, «L'âme des sons. Gordes, le Relié, 237 pp. », Abstracta Iranica [En ligne], Volume 26 | 2005, document 473, mis en ligne le 15 décembre 2005, consulté le 25 septembre 2020. URL : http:// journals.openedition.org/abstractairanica/714

Ce document a été généré automatiquement le 25 septembre 2020.

Tous droits réservés 


\title{
L'âme des sons. Gordes, le Relié, 237 pp.
}

\author{
Sāsān Fāțemī
}

1 L'ouvrage est entièrement consacré à l'étude de la musique d'un maître incontesté du tanbūr kurde, Nūr-'Alī Elāhī, grand penseur et mystique Ahl-e Haqq, décédé en 1974. Sans avoir l'intention d'écrire une hagiographie et de procéder à une analyse systématique de sa musique, l'A. après avoir présenté une courte biographie de l'ostād, mettant en relief sa vie spirituelle et ses expériences mystiques, étudie différents aspects de sa musique en s'appuyant, généralement, sur les dires de ses proches ainsi que sur ceux du maître lui-même. Son approche étant phénoménologique, il considère comme secondaire la question de la "réalité » des phénomènes décrits et essaye de découvrir leur fonctionnement (p. 229). Suivant la méthode qu'il avait déjà adoptée pour un article sur un chanteur de la musique classique iranienne (H. 'Asgarī), il donne la parole au maître, à ses proches et aux auditeurs de sa musique tout en alternant ces paroles avec ses propres commentaires, ce qui lui permet de dégager les particularités de la musique du maître perçues à la fois par le musicien lui-même et par les auditeurs.

2 Mis à part les aspects techniques de cette musique, ces particularités résident surtout dans ses effets et dans sa capacité de communication. C'est une musique à la fois artistique et spirituelle (p. 161). Elle est, d'une part, techniquement remarquable par sa richesse d'ornementation, par la diversité de son jeu instrumental, par la liberté de son parcours modal, etc. et c'est d'autre part, une musique qui fait « communiquer les plans terrestre et céleste ", sur un axe vertical, et permet «au maitre de communiquer aux auditeurs quelque chose de l'intensité de son état spirituel », sur un axe horizontal (p. 162).

3 En examinant les conditions de fonctionnement des musiques spirituelles, y compris celle du maître Elāhī, l'A. attire notre attention sur le principe de proximité qui correspond aux notions de concentration, de finesse, de subtilité et d'intériorité (p. 156). Selon ce principe, on ne peut apprécier l'art moyen-oriental, en général, qu'en l'examinant de près. C'est de cette manière qu'on arrive à saisir toute sa finesse et tous les détails significatifs qui échappent normalement au regard d'un observateur non 
initié. La musique de l'Ostād Elāhī aussi s'apprécie selon ce principe esthétique qui nous permet d'avoir une perception plus fine de ses détails techniques ainsi que de l'état intérieur du musicien transmis par la musique. Il reste que pour bénéficier pleinement de sa musique il faut une préparation mentale pour l'écoute qui se base sur l'intention de l'auditeur, sur une volonté de capter ces états intérieurs et d'être capté par le hạal: «tout dépend de l'intention» (p. 97).

4 L'ouvrage comporte six chapitres plus trois dossiers qui présentent le répertoire du maître, ses enregistrements, ses élèves, la tradition Ahl-e Haqq et, finalement, le système musical du tanbūr et sa technique. Il a été traduit en persan par S. Faḍā'elī et publié par la maison d'édition Jeyḥūn en 2003.

INDEX

Mots-clés : Musique mystique

Keywords : Mystical music, tanbūr nompropre Ostād Elāhī

Thèmes : 17.1.Musique

\section{AUTEURS}

\section{SĀSĀN FĀṬEMĪ}

Université de Téhéran 